\title{
Kosovo and Balkan Stability
}

\section{Gordon N. Bardos *}

As the process of determining Kosovo's future status enters its final stages, everyone's worst case scenario - a unilateral declaration of independence by Kosovo Albanian authorities, without United Nations Security Council approval-appears increasingly likely. The diplomatic mismanagement of this process is largely to blame for the fact that the international community has arrived at such an impasse. The most pressing issue now is how all the major international actors (e.g., the United States, the European Union, Russia, NATO, the OSCE, etc.) involved can react to and control the likely consequences of such a development.

The guiding assumption of current U.S. policy (and of a large number of Balkan observers ${ }^{1}$ ) is that the Balkans are relatively stable, and that whatever spillover effects may result from the outcome of Kosovo's future status can be controlled; in fact, in this view, the greatest threat to Balkan stability comes from not resolving Kosovo's status. These assumptions are also either explicit or implicit in the so-called "Ahtisaari Plan" for Kosovo presented to the UN Security Council in March 2006. ${ }^{2}$

Several strong arguments favor moving forward with determining Kosovo's future status: respecting the right to self-determination of the vast majority of Kosovo's inhabitants; the fact that it is difficult to conceive of a situation in which, after eight years of international administration, it would be possible to return Kosovo to any form of meaningful rule from Belgrade; and the fact that Kosovo's unresolved status makes it difficult for Kosovo to receive access to several sources of development aid from international financial institutions like the World Bank and the International Monetary Fund.

What remains open to valid debate, however, are the timing and the pace of the determination of Kosovo's future status, the actual state of Balkan stability, and how an independent Kosovo is likely to affect it. In contrast to the assumptions governing U.S. policy noted above, a strong argument can be made that the current political moment in the Balkans is extremely delicate. South Eastern Europe is experiencing its most profound period of change since the end of the Kosovo

Gordon N. Bardos is Assistant Director of the Harriman Institute at Columbia University's School of International and Public Affairs. Information for this article was drawn from three research trips the author made to the Balkans during the course of 20062007, visiting Bosnia-Herzegovina, Macedonia, Montenegro, and Serbia.

1 See, for instance, the signatories of "Kosovo: Breaking the Deadlock," available at: www.usip.org/pubs/usipeace_briefings/2007/0914_kosovo.html.

2 Formally known as the "Report of the Special Representative of the Secretary-General on Kosovo's Future Status," available at: www.unosek.org/docref/report-english.pdf. 
war in 1999. In June 2006, Montenegro declared its independence from the stillborn Union of Serbia and Montenegro; during the course of 2006-07, new governments came to power in Bosnia-Herzegovina, Macedonia, and Serbia (with elections due in Croatia and Kosovo). And looming over everything is the aforementioned final decision on Kosovo's future status. Such a quickly changing political landscape carries with it numerous dangers; as was seen in the Balkans in the 1990 s, the process of changing borders and creating new states is rarely peaceful. ${ }^{3}$

\section{The Changing Balkan Political Landscape}

All of these events are occurring at a moment when several key developments are significantly changing the political dynamics of South Eastern Europe. The first three developments are related to the weakening of the three pillars on which Balkan stability has rested for much of the past decade: the U.S. military presence in the region, the prospect of EU accession for the Western Balkan states in the foreseeable future, and the weakening of political elites in Bosnia-Herzegovina, Macedonia, and Serbia that support the international agreements that have been the cornerstone of Balkan stability for the past dozen years. These agreements include the Dayton Peace Accords, which ended the war in Bosnia; U.N. Security Council Resolution (UNSCR) 1244, which provided the political solution that ended the Kosovo war in 1999; and the August 2001 Ohrid Accords, which regulated an end to Macedonia's internal conflict. It should not be surprising that, given so much political and strategic uncertainty, the democratic transition throughout the region has lagged over the past year, as is evident from the European Union's 2007 progress reports on each of the individual Balkan countries. ${ }^{4}$ Added to these developments is one other that will profoundly influence Balkan stability in the years to come: the return of Russia as an increasingly important political and economic player on the regional stage.

Given these developments, there are already many indicators suggesting that the political and security situation in the southern Balkans - in fact, throughout East Central Europe - is becoming more rather than less unstable at this political

3 In fact, the violence accompanying the breakup of the former Yugoslavia was, in historical terms, the norm, and not a violent aberration. As Valerie Bunce has noted, "Regime and state dissolution is rarely so graceful as what we saw in 1989-1992. What happened in Yugoslavia is, unfortunately, the historical norm." Bunce, Subversive Institutions: The Design and the Destruction of Socialism and the State (Cambridge: Cambridge University Press, 1999), 142.

4 The EU's progress reports for the countries of South Eastern Europe, released in November 2007, can be found at: http://ec.europa.eu/enlargement/key_documents/reports nov_2007_en.htm. 
moment. ${ }^{5}$ On the positive side, one factor contributing to regional stability is that every country in the region is now either a full member of NATO (Bulgaria, Greece, Hungary, Romania, and Slovenia) or a member of NATO's Partnership for Peace (PfP) program (Albania, Bosnia-Herzegovina, Croatia, Macedonia, Montenegro, and Serbia; Albania, Croatia, and Macedonia are hoping to be invited to become full members at the NATO summit in Bucharest in April 2008, although this possibility looks increasingly unlikely for both Albania and Macedonia). Similarly, a number of regional free trade and energy cooperation agreements have been signed amongst the Balkan countries in recent years, which have slowly been serving to integrate the region. Most notable among these has been the June 2006 signing of the treaty establishing the Energy Community of South East Europe, whose goal is to create an integrated electricity and natural gas market for the region (and its integration with the EU countries). Another important milestone was the expansion of the Central European Free Trade Association (CEFTA) to the countries of South Eastern Europe, an agreement that was signed in Brussels on 19 December $2006 .{ }^{6}$

Despite such positive developments, there is nevertheless reason for concern over whether these institutional security and economic arrangements will outweigh the cumulative impact of the Balkans' changing political dynamics. While a return to the large-scale violence that afflicted the Balkans in the 1990s is unlikely, the threat of violence has not been eliminated. Rather, the nature and scale of the threat to Balkan stability has changed. Over the coming years, the greatest threats to Balkan stability will come from relatively small bands of ethnic militants and guerrillas, often allied with or even identical to organized crime organizations

As F. Stephen Larrabee has recently argued, "The recent rise of nationalist and populist forces in several countries in Eastern Europe ... threatens to undermine the reform process. Enlargement fatigue in the EU and growing calls for protectionism within Western Europe could further hinder continued efforts to create a single European market and fully integrate the new EU members. At the same time, the balance of power is shifting on Eastern Europe's outer periphery.... These changes have gone largely unnoticed by policymakers in Washington despite the important implications they have for U.S. interests." See Larrabee, "Danger and Opportunity in Eastern Europe," Foreign Affairs 85:6 (November/December 2006).

6 See Milica Delevic, "Regional Cooperation in the Western Balkans," European Union Institute for Security Studies (EU-ISS), Chaillot Paper no. 104 (July 2007), 5-6. 
smuggling weapons, drugs, and human beings, and the infiltration of Islamic extremist organizations. ${ }^{7}$

Despite the more limited scale of this threat, however, the ability of these relatively small groups of extremists to derail political and economic reform in the region, or to derail the region's Euro-Atlantic accession hopes, should not be underestimated. Such groups have assassinated a prime minister in Serbia, set back Macedonia's EU accession process significantly, and made Kosovo a regional black hole mired in crime and corruption. Unless the U.S., the EU, and NATO devote more time and resources to the Balkans, it is doubtful that the Balkan states will have the internal strength to overcome these forces on their own.

At this point it is worth examining in more detail some of the key developments that are changing the political dynamics of the region. I will begin with the changes to the three pillars of Balkan stability over the past decade: the removal of the U.S. military presence in the region, the region's ever-dimmer hopes for EU accession, and the weakening of political elites that support the political and territorial status quo in South Eastern Europe.

\section{The U.S. Military Presence in the Balkans}

The U.S. has pulled its troops out of Bosnia, and the current international peacekeeping force - the "European Force" (EUFOR) - numbers less than 4,000 troops. ${ }^{8}$ The NATO force in Kosovo currently totals approximately 16,000 troops, some $2-3,000$ of whom are U.S. forces.

Behind these numbers, however, lie three unfortunate realities. First, because of operations in Afghanistan and Iraq, the U.S. military is both over-extended and exhausted, and hence extremely unlikely to be able to react to any eruption of violence in the region. Second, there are considerable problems with relying so much on European forces for security. The European troops garner little respect from local militants, and they lack the capacity to respond effectively to a quick escalation of violence. Third, both the U.S. and Western European countries have repeatedly shown their unwillingness to risk their troops in the Balkans. This has

7 As the former head of the OSCE mission to Bosnia-Herzegovina, Ambassador Robert Barry, noted in 1999: "Organized crime and corruption are a more serious threat to security and stability than military forces. The growing nexus between extremist politicians, organized crime and the former communist intelligence services is becoming ever stronger, and this is the single greatest obstacle to democratic reform, economic investment and membership in Euro-Atlantic institutions. Rolling back the mafia must be a central goal of the Stability Pact, NATO, the EU, and the OSCE." See Barry's comments in the Frankfurter Allgemeine Zeitung (20 July 1999).

During an October visit to Bosnia, in the course of a 900 kilometer trip around the country I encountered a total of three EUFOR soldiers - sitting in a café outside of Bijeljina. 
been evident from the Srebrenica massacres in 1995, to NATO's bombing campaign against Serbia in 1999, to NATO's failure to prevent the infiltration of militants from NATO-occupied Kosovo into Macedonia and southern Serbia in 2000-01, to the March 2004 pogroms in Kosovo against Serbs and other non-A1banian ethnic groups.

This third fact gives extremists in the region a distinct psychological advantage. Knowing that NATO and other international organizations are unwilling to suffer casualties in the Balkans allows extremists to set the political agenda, determine the timetable for future action, and create facts on the ground. This has most clearly been seen in the Albanian insurrections in Kosovo in 1998-99, in Macedonia in 2000-01, and again in Kosovo in March 2004. In sum, absent a substantial U.S. military commitment in the region and a visible determination to confront extremists (which has been lacking up until now), Balkan stability depends to an uncomfortable degree on local militants, who can determine when and where it suits their interests to confront local governments, and hence derail the region's Euro-Atlantic integration efforts.

\section{The Promise of EU Accession}

Strategic uncertainty in South Eastern Europe is also increasing due to the fact that, apart from Croatia, the countries of the Western Balkans are not being given firm assurances that they will be allowed to join the European Union anytime soon. Internal EU difficulties related to enlargement fatigue and debates about absorption capacity are increasing both uncertainty and skepticism in South Eastern Europe as to whether these countries will ever be invited to join the union. This uncertainty makes it commensurately more difficult for local politicians to endorse the political and economic reforms needed for EU membership - predictably, government officials are hesitant to take the personal political risks for decisions that will only show tangible results eight or ten years down the line. Former Macedonian Prime Minister Vlado Buckovski expressed the concerns of many Balkan political leaders when he noted that, absent a clear timetable from the EU as to when the various countries of the Western Balkans may accede to membership, "it will be very difficult for us pro-Western and pro-European reformers to continue the political fight." 9

One of Europe's most knowledgeable Balkan hands, Swedish Foreign Minister Carl Bildt, has echoed Buckovski's concerns, warning that if the EU's doors are closed to the remaining Balkan states, it would "take away the guiding beacon which has guided the reform policies of the region for the past few years. Instead of the magnet of European integration, we might well go back to seeing the poli-

9 Nicholas Wood, "Nationalism Still a Threat in Macedonia," The New York Times (4 July 2006). 
cies of the region driven by the fears and prejudices of nationalism." quently, unless the EU begins laying out a more concrete road map for when the Western Balkan countries can expect to join the union, there is a danger that the reform process in the region will slow down.

\section{The Status Quo Elites}

Strategic uncertainty in the region is also threatened by the relative weakness of political elites in Bosnia-Herzegovina, Macedonia, and Serbia who support the current regional status quo, defined as the political and territorial agreements set forth in the Dayton Peace Accords, U.N. Security Council Resolution 1244, and Macedonia's August 2001 Ohrid Accords.

Over the past several years, Serbia has suffered a number of setbacks: the assassination of a prime minister, three failed attempts to elect a president during the course of 2002-03, the inability of pro-democratic parties to form a government for three and a half crucial months from January-May 2007, and the postponement of the signing of a Stabilization and Association Agreement with the EU in May 2006 because of Serbia's failure to turn over indicted war criminals (or, at least, its failure to convince ICTY prosecutors that every effort was being made to do so). ${ }^{11}$ Nevertheless, what is remarkable about Serbia's post-Milošević transition to democracy is that, despite these problems, the country is making respectable progress, and a number of indicators suggest that Serbia is, in comparative regional terms, doing as well as can be expected. It is somewhat behind EU member states such as Bulgaria, Romania, and Slovenia, approximately equal to Croatia, and on most measures is ahead of Albania, Bosnia-Herzegovina, Macedonia, and Montenegro. $^{12}$

A decision on Kosovo's future status that is detrimental to Belgrade's interests, however, could significantly undermine the position of pro-democratic parties in Serbia over the coming months. While parties supporting Serbia's EU accession

${ }^{10}$ See Carl Bildt, "On the Periphery of Europe," Internationale Politik (Transatlantic Edition) (Summer 2006): 27.

11 The criticism is in many ways unfounded; the Serbian government official Rasim Ljajic, for instance, has pointed out that 91 percent of those indicted by the Hague (42 out of 46) have been turned over to the Hague. Ljajic also claimed that, of 1,692 official documents that the ICTY has requested, 98 percent have been turned over. See Ljajic's comments in "Del Ponte: Predložiću uslovjavanje," B92 (26 October 2006), available at: www.b92.net/info/vesti/index.php?yyyy $=2007 \& \mathrm{~mm}=10 \& d d=26 \&$ nav_category $=64$ \&nav_id=269491 (accessed on 26 October 2007).

12 See, for instance, Serbia's rankings on the following indices: the World Bank's "Ease of Doing Business" rankings, available at www.doingbusiness.org/economy/rankings; Freedom House's Nations In Transit Series, available at: http://www.freedomhouse.org/ template.cfm?page $=17 \& y e a r=2006$; and Transparency International's Corruption Perceptions Index, available at: www.transparency.org. 
efforts - the Democratic Party (DS); the Democratic Party of Serbia (DSS); G17 Plus; the Serbian Renewal Movement (SPO); the Liberal Democratic Party (LDP); and a number of smaller ethnically-based minority parties - won a convincing victory over the Milošević-era ruling parties (the Serbian Radical Party, or SRS, and the Socialist Party of Serbia, or SPS), support for some of these parties is considered to be soft, and a decision to grant Kosovo independence could increase support for the parties of the old regime. A public opinion poll conducted in Serbia in June, for instance, showed that roughly half of those polled said that Serbia should sacrifice EU integration for the sake of Kosovo. The same poll also showed that the number of people who believe that Serbia should model itself on Russia instead of on EU countries is growing, while those who believe that the EU provides the better political and social model is decreasing.

Political elites in Skopje are similarly under severe pressure for a number of reasons. Despite progress in economic reform and tackling corruption, the new Macedonian government elected in July 2006, led by the International Macedonian Revolutionary Organization-Democratic Macedonian Party of National Unity (VMRO-DPMNE) leader Nikola Gruevski, has been less than successful in dealing with Macedonia's fragile internal political situation. The largest Albanian political party in Macedonia, former guerrilla leader Ali Ahmeti's Democratic Union for Integration (DUI), has been engaged in an on-again/off-again boycott of the Macedonian parliament throughout the new government's tenure, which has made it impossible to pass important pieces of political and economic reform legislation required for EU accession. Relations between the two main ethnic-Macedonian parties have also deteriorated.

Added to these problems on the macro-political level is the deteriorating security situation in the country. In a spate of recent incidents in recent months (on 10 September, 24 October, and 7 November 2007), Macedonian policemen and ethnic Albanian gunmen have come into conflict in areas adjacent to Kosovo, resulting in numerous deaths. One ethnic-Albanian village near the Kosovo border, Tanusevci, has announced plans to hold a referendum on unification with Kosovo. The former Albanian guerrilla leader Ali Ahmeti publicly warned on 26 October 2007 that Macedonia could be facing a crisis similar to that which erupted in 2000-01 if the Gruevski government does not move forward on providing pensions to former Albanian guerrillas and in encouraging official use of the Albanian language. And, adding to the level of anxiety, Wahhabists have reportedly taken control of several important mosques in Skopje and Tetovo. All of these developments are causing increasing concern in Brussels and elsewhere about Mace- 
donia's ability to meet EU standards, and on several occasions over the past year EU officials have criticized Macedonia's lack of progress in this regard. ${ }^{13}$

Bosnia-Herzegovina is currently going through its worst political crisis since the end of its civil war in November 1995. Twelve years into the Dayton Peace Process, Bosniacs, Croats, and Serbs still have not reached even the minimal amount of consensus needed to allow the Office of the High Representative to shut down, as had been scheduled in mid-2006. The Bosniac vision of a centralized state (which, as the largest ethnic group, they would be in a position to dominate) remains completely at odds with Serb (and, to some extent, Croat) visions of a more decentralized government that grants each ethnic group significant degrees of self-government. Given these difficulties, granting Kosovo independence is likely to increase centrifugal pressures in Bosnia. One public opinion poll conducted in September 2005 in Bosnia's majority-Serb entity, the Republika Srpska (RS), for instance, found that 75 percent of those polled thought the RS should secede from Bosnia if Kosovo were granted independence. ${ }^{14}$ Consequently, if the process by which Kosovo's future status is mismanaged, the consequence is likely to drive the wedge between Bosnia's ethnic groups even deeper. And in both Bosnia and Macedonia, the deterioration of the political situation will make it even more difficult for these countries to adopt the political and economic reforms necessary for EU integration.

\section{Russia's Return to the Balkans}

As these pillars that have supported Balkan stability over the past several years are weakening, a new variable has been introduced into the Balkan strategic equation: the return of Russia as a major player in Balkan politics. This has been seen most prominently in Russia's role in preventing the UN Security Council from endorsing the Ahtisaari Plan during the course of 2007, but it is visible in a number of other ways as well, most especially in Russia's increasingly prominent economic role in the region. In Montenegro, Russians have bought the republic's largest industrial enterprise; in Bosnia, the largest oil refinery; in Macedonia, Lukoil is planning a major expansion of its operations; in Serbia, Russia is providing the capital to refurbish the hydro-electric plant at the Iron Gates of the Danube, Serbia's main source of electricity; and in March 2007, Russian President Vladimir

${ }^{13}$ For instance, on 8 February 8 2007, EU Enlargement Commissioner Olli Rehn said while visiting Skopje, "We had higher expectations from Macedonia after it gained candidate status in December 2005." In October 2007, the EU foreign policy chief criticized Macedonian leaders for "political immaturity."

14 See the public opinion survey conducted by Agencija Partner Marketing of Banja Luka in mid-September 2005. A representative sample of 850 participants of legal voting age was included in the poll. 
Putin traveled to Greece to sign an agreement with his Bulgarian and Greek counterparts to build a new pipeline to carry Russian oil from the Black Sea to the Aegean.

The political and diplomatic consequences of Russia's return to the regional stage in the Balkans will be significant. During the 1990s, the U.S. and NATO largely had a free hand in determining diplomatic and political solutions to the problems that emerged after the disintegration of the former Yugoslavia, and Moscow during this time was essentially unable to oppose such actions or to protect its own interests. This period in Balkan history has clearly ended. Dealing with the Balkans will be considerably more complex in the coming years, as Russia's return to the region provides the countries of South Eastern Europe with more political and diplomatic room to maneuver in dealing with both the EU and the U.S. This is already evident in the case of Serbia. In October 2007, for instance, the Democratic Party of Serbia (DSS), led by current Serbian Prime Minister Vojislav Koštunica, officially endorsed a platform calling for Serbia to become a neutral country. ${ }^{15}$

\section{Likely Future Political Trajectories}

Whatever the outcome of the negotiations on Kosovo's future status, there are several things we can already say with considerable certainty about what will happen in South Eastern Europe in the months to come. Kosovo is and will likely remain for some time among the poorest states in Europe. Official estimates claim that 50-60 percent of Kosovo's population (half of which is under the age of twenty-six) is unemployed. Compounding these economic problems is the fact that Kosovo has an extremely polarized political system, with loyalties divided mainly along regional and clan lines. Virtually the only thing uniting Kosovo's current political leadership is the issue of independence; absent that, Kosovo's fractured political system will have a hard time dealing constructively with the many problems Kosovo faces. Primary among these will be the seemingly permanent conflict that separates Kosovo along the Ibar River, north of which approximately 4050,000 Serbs live in an enclave directly adjacent to Serbia proper. No serious plans exist as to how to integrate either the people or the territory into an independent Kosovo. In fact, there is a serious possibility that the Serbs north of the Ibar may declare that they do not recognize a unilateral declaration of independence by Pristina and will continue to adhere to UNSCR 1244, which states that Kosovo is a sovereign part of Serbia.

Second, for the past eight years the worst human rights abuses in Europe have taken place in Kosovo, and it is difficult to see how independence will improve the

15 The DSS' declaration on military neutrality, passed on 10 October 2007, can be found at www.dss.org.yu/vesti/vest.php?id=4850. 
situation; in fact, it will probably make it worse. International officials such as former United Nations Interim Administration in Kosovo (UNMIK) head Soren Jessen-Petersen, have publicly decried the fact that in twenty-first-century Europe ethnic minorities are forced to live in barbed-wire enclosed ghettoes protected by NATO troops. This situation has persisted despite the presence of thousands of international bureaucrats in Kosovo and upwards of 17,000 NATO soldiers, and despite the fact that Kosovo has received twenty-five times more international aid per capita than Afghanistan. ${ }^{16}$ This situation has persisted, moreover, despite the considerable leverage the international community could have exerted to improve the human rights situation in Kosovo for the sake of a quicker route to independence. If Kosovo's independence is recognized, however, political logic suggests that the international community will have even less leverage with which to compel Kosovo's compliance with international human rights standards.

Third, empirical evidence from South Eastern Europe also shows that state independence in and of itself does not automatically attract foreign direct investment. Albania, for instance, attracts the lowest amounts of foreign direct investment in the region because of political instability and governmental corruption. To be sure, bureaucratic red tape within international financial institutions (IFIs) has meant that Kosovo has been denied access to important sources of development and investment capital, a problem that needs to be urgently rectified. But there are several examples of non-sovereign entities (e.g., Taiwan) receiving IFI support. In sum, Kosovo's sovereign status will probably have little impact on the amount of foreign investment it receives until it seriously addresses the problems mentioned above: political instability, corruption, the human rights situation, etc. Meanwhile, there is no insurmountable reason for Kosovo to be denied access to World Bank and International Monetary Fund resources, even with its current status.

Fourth, the past 150 years of Balkan history, more recent experience in South Eastern Europe, and the simple logic of Balkan ethnoconfessional nationalism all suggest that the creation of new states and the changing of borders has consequences for neighboring states. In this case, Macedonia, Montenegro, Serbia, Bosnia-Herzegovina, and perhaps Albania itself will be most directly affected. Macedonia is likely to face the greatest difficulties. With two million Albanians living to the north in a potentially independent Kosovo, and three million Albanians living to the west in another independent state (Albania), it is hard to see why 500,000 ethnic Albanians will remain satisfied in a multiethnic state (Macedonia) in which they are a minority. As we saw in the 1990s in the cases of the Croats and Serbs in Bosnia, such a structural situation is tailor-made for national-

${ }^{16}$ According to Iain King and Whit Mason, Peace at Any Price: How the World Failed Kosovo (Ithaca, NY: Cornell University Press, 2006), 21. 
ist/irredentist/separatist conflicts (at least in Bosnia-Herzegovina the three ethnic groups speak the same language).

In sum, recent Balkan history provides little hope for optimism that Macedonia will be able to weather the fallout from Kosovo becoming independent. Extremists are already active and mobile across the region's porous borders-Albanian militants, for instance, have over the past few years fomented violence in Serbia's Presevo Valley, planned violence in Montenegro, and nearly provoked a full-scale ethnic war in Macedonia in 2000-01 when former Kosovo Liberation Army (KLA) personnel set their sights on the one former Yugoslav republic that managed to escape from the disintegrating federation peacefully. In Serbia and northern Kosovo paramilitaries have similarly announced their presence, although they have not engaged in any serious actions.

Moreover, the consistent statements by many Albanian politicians in the southern Balkans that they have no intention of creating a "Greater Albania" or a "Greater Kosovo" should not be taken seriously (the same, of course could be said of many Serb politicians, and some Croat as well). The literature on ethnic conflict often shows how ethnic groups increase or decrease their demands as conditions change, or engage in a "strategic expression of preferences" and "preference falsification" as circumstances warrant. ${ }^{17}$ If Kosovo is granted independence, Albanian demands in Macedonia are likely to significantly increase.

Fifth, the consequences of a mismanaged future status process are likely to be much more severe for Serbia - and, by extension, for South Eastern Europe - than is recognized in the best-case scenario hoped for by Washington. As mentioned above, a public opinion poll conducted in Serbia in June 2007 showed that roughly half of those polled said that Serbia should sacrifice EU integration for the sake of Kosovo. The same poll also showed that the number of people who believe that Serbia should model itself on Russia instead of on EU countries is growing (those believing that the EU provides the better social model is decreasing). ${ }^{18}$ Proponents of the best-case scenario are unconcerned by such developments, arguing that if Serbia wants to isolate itself over Kosovo that is Serbia's problem. Unfortunately, such views are both politically and strategically myopic. In reality, an isolated Serbia, or one increasingly drifting towards Russia, is much more than

${ }^{17}$ On preference falsification and strategic expressions of preferences in ethnic conflict, see Hudson Meadwell, "A Rational Choice Approach to Political Regionalism," Comparative Politics 23 (July 1991): 402; Timur Kuran, "Now out of Never: The Element of Surprise in the East European Revolution of 1989," World Politics 44 (1991): 7-48; and Anthony Smith, "Nationalism, Ethnic Separatism and the Intelligentsia," in National Separatism, ed. Colin H. Williams (Vancouver, Canada: University of British Columbia Press, 1982), 18-19.

${ }^{18}$ See "Istraživanje javnog mnenja Srbije, rana jesen 2007 godine," Center for Free Elections and Democracy (Belgrade: September 2007), available at: www.cesid.org. 
Serbia's problem. Serbia's size and central location in the Balkan Peninsula makes it in many ways the most strategically important country in the region, and the large number of Serbs living in neighboring states increases its importance. Moreover, forcing Serbia to choose between Kosovo or the EU, or between the EU and Russia, will again lead to a division of the Balkan Peninsula between rival power blocs, precisely at a rare historical moment when all the states of South Eastern Europe still share the same domestic and foreign policy goals: becoming market democracies integrated into the EU. Avoiding a "who lost Serbia" debate similar to the "who lost Russia" debate that is already emerging requires a much more careful approach to resolving Kosovo's future status. ${ }^{19}$

Sixth and finally, the best-case scenario also ignores much of what we already know about how insufficiently considered actions by the U.S. and some EU countries can affect strategic relations between the great powers. Regardless of their position on the political spectrum, for instance, most Russians almost uniformly condemned NATO's attack on Serbia in 1999, and it is no coincidence that Vladimir Putin and other siloviki in the Russian establishment rose to power precisely at this time. The United States' willingness to bypass the UN Security Council to achieve its own interests, visible in the decisions to attack Serbia in 1999 and Iraq in 2003, have increased the sense in Moscow and many other places that the U.S. is wielding its current power irresponsibly. Instead of signaling that the U.S. supports multilateral approaches to regional security problems, recognizing a unilateral declaration of independence by Pristina will almost certainly set back international efforts to find peaceful, multilateral solutions to other frozen conflicts around the world.

Given all of these considerations, much can clearly still go wrong in South Eastern Europe. But the current political moment in the Balkans also presents a very rare historical opportunity. For the first time in centuries, the region is not divided between rival empires or power blocs. What is even more unusual is that all the Balkan states (for the moment, at least) share the same foreign and domestic policy goals: internally, political democratization and the creation of market economies, and externally, integration into NATO, the EU and other Euro-Atlantic institutions. The return of Russia means that these processes will undoubtedly be more complicated than they might have been in the 1990s. Ultimately, however, whether South Eastern Europe's Euro-Atlantic integration efforts succeed or fail largely depends on decisions that will be made outside the region. What is clear, however, is that this is a rare political moment when historical change can be accomplished in the Balkans for a relatively modest price.

19 See, for instance, Dimitri K. Simes, "Losing Russia: The Costs of Renewed Confrontation," Foreign Affairs 86 (November/December 2007): 36-52. 
THE QUARTERLY JOURNAL

\section{Bibliography}

Barry, Ambassador Robert. "Barry's comments." Frankfurter Allgemeine Zeitung (1999).

Bildt, Carl. "On the Periphery of Europe." Internationale Politik (Transatlantic Edition)(2006): 27.

Bunce, Valerie. Subversive Institutions: The Design and the Destruction of Socialism and the State. Cambridge: Cambridge University Press, 1999.

Delevic, Milica. Regional Cooperation in the Western Balkans. European Union Institute for Security Studies (EU-ISS), 2007.

F. Larrabee, Stephen. "Danger and Opportunity in Eastern Europe." Foreign Affairs 85, no. 6 (2006).

Freedom House's Nations In Transit Series., 2006.

Istraživanje javnog mnenja Srbije, rana jesen 2007 godine. Belgrade: Center for Free Elections and Democracy, 2007.

King, Iain, and Whit Mason. Peace at Any Price: How the World Failed Kosovo. Ithaca, NY: Cornell University Press, 2006.

Kuran, Timur. "Now out of Never: The Element of Surprise in the East European Revolution of 1989." World Politics, no. 44 (1991): 7-48.

Ljajic, Rasim. "Predložiću uslovjavanje." Del Ponte (2006).

Meadwell, Hudson. "A Rational Choice Approach to Political Regionalism." Comparative Politics, no. 23 (1991): 402.

Report of the Special Representative of the Secretary-General on Kosovo's Future Status., 2007.

Simes, Dimitri K. "Losing Russia: The Costs of Renewed Confrontation." Foreign Affairs, no. 86 (2007): 36-52.

Smith, Anthony. "Nationalism, Ethnic Separatism and the Intelligentsia." In National Separatism, 18-19. Vancouver, Canada: University of British Columbia Press, 1982.

The EU's progress reports for the countries of South Eastern Europe, released in November 2007., 2007.

Wood, Nicholas. "Nationalism Still a Threat in Macedonia." The New York Times (2006). 